\title{
Faktor Penyebab Siswa tidak dapat Menyelesaikan Soal Materi Limit Fungsi Aljabar
}

\author{
1Syintia Dewi Ananta Shinta Dewi, ${ }^{*}$ Yenita Roza, ${ }^{1}$ Maimunah \\ ${ }_{1}^{1}$ Program Studi Magister Pendidikan Matematika, FKIP, Universitas Riau, Jl. Kampus Bina Widya \\ KM 12.5 Pekanbaru 28293, Indonesia
}

${ }^{*}$ Corresponding Author e-mail: yenita.roza@lecturer.unri.ac.id

Received: April 2020; Revised: June 2020; Published: July 2020

\begin{abstract}
Abstrak
Indikasi banyaknya jumlah siswa yang tidak dapat menyelesaikan soal limit fungsi aljabar yang diberikan di kelas XI MAN 1 Pekanbaru, menggambarkan adanya permasalahan siswa. Penelitian ini bertujuan untuk menganalisis faktor penyebab siswa tidak menyelesaikan soal limit fungsi aljabar, khususnya siswa di kelas XISMA/MA. Metode penelitian yang digunakan adalah penelitian deskriptif kualitatif. Subjek pada penelitian ini adalah 22 orang siswa kelas XI IIS 4 MAN 1 Pekanbaru tahun pelajaran 2019/2020. Instrumen yang digunakan dalam penelitian ini adalah angket untuk mengetahui faktor penyebab siswa tidak menyelesaikan soal limit fungsi aljabar berupa faktor fisiologis, faktor psikologis, faktor materi, faktor lingkungan sekolah, faktor lingkungan keluarga, dan faktor lingkungan masyarakat. Hasil analisis menunjukkan bahwa faktor terbesar yang menyebabkan siswa tidak menyelesaikan soal materi limit fungsi aljabar yaitu faktor materi $(50 \%)$ dan yang paling sedikit adalah faktor fisiologis (18\%). Hasil penelitian ini dapat menjadi rujukan bagi guru untuk dapat lebih menekankan konsep limit fungsi dalam bentuk akar dengan menggunakan strategi dan model pembelajaran yang sesuai dengan karakteristik siswa dan kebutuhan materi.
\end{abstract}

Kata Kunci: Faktor Penyebab, Limit Fungsi Aljabar

\section{Students' Causative Factor Unable to Solve The Algebraic Limit Function's Problems}

\begin{abstract}
The indication that many of the students were not able to solve the algebraic function limit's problems given in class XI MAN 1 Pekanbaru, it pointed out that there were some student's problem. This research aims to analyze the factors that caused many of the students were not able to solve the algebraic function limit's problems, especially students in class XI SMA/MA. The method used in this research was descriptive qualitative research. The subject of this research were 22 students of class XI IIS 4 MAN 1 Pekanbaru in the academic year 2019/2020. The instrument used in this research was a questionnaire to determine the factors caused students were not able to solve the algebraic function limit problems in the form of physiological factors, psychological factors, topic factors, school environmental factors, family environmental factors, and community environmental factors. The analysis results showed that the biggest factor caused students were not able to solve the problems about algebraic function limit was the topic factors (50\%) and the least factor was the physiological factors (18\%). The results of this study can be a reference for teachers to be able to emphasize the concept of limit functions in the form of roots by using strategies and learning models that are in accordance with student characteristics and material needs. Keywords: Causative Factor, The Algebraic Limit Function
\end{abstract}

How to Cite: Dewi, S., Roza, Y., \& Maimunah, M. (2020). Faktor Penyebab Siswa tidak dapat Menyelesaikan Soal Materi Limit Fungsi Aljabar. Jurnal Penelitian dan Pengkajian Ilmu Pendidikan: eSaintika, 4(2), 134-150. doi:https:// doi.org/10.36312/e-saintika.v4i2.206 


\section{PENDAHULUAN}

Pembelajaran merupakan proses interaksi antara siswa dengan guru dan sumber belajar, pada suatu lingkungan belajar (Suardi, 2018). Jika siswa memperoleh proses pembelajaran yang menarik, maka informasi terkait materi pelajaran yang diterima siswa akan lebih optimal, sehingga tujuan pembelajaran yang diharapkan juga dapat tercapai dengan maksimal.

Salah satu unsur penting dalam proses pembelajaran adalah guru. Guru sangat berperan dalam proses perkembangan dan meningkatkan prestasi belajar siswa, diantaranya dalam membangun konsep terkait materi pelajaran dan meningkatkan motivasi siswa. Hal ini diperkuat dengan hasil penelitian (Azka, 2019) yang menyatakan bahwa siswa yang memiliki motivasi belajar yang tinggi, maka prestasi belajarnya akan lebih tinggi dibandingkan dengan siswa yang memiliki motivasi belajar yang rendah, dan siswa yang memiliki persepsi terhadap gaya mengajar guru yang baik maka prestasi belajarnya akan lebih tinggi dibandingkan dengan siswa yang memiliki persepsi terhadap gaya mengajar guru yang kurang. Maka, sebaiknya guru menggunakan model/metode mengajar yang sesuai dengan karakteristik dan kebutuhan siswa.

Tingkat pemahaman atau kemampuan yang dimiliki setiap siswa terhadap suatu materi pelajaran berbeda-beda. Perbedaan tersebut dapat disebabkan oleh kurangnya motivasi siswa pada materi yang disampaikan, kurangnya usaha siswa untuk memahami materi tersebut, dan siswa mendapat kesulitan dalam belajar, yaitu ketika harus menguasai bagian-bagian yang sukar, misalnya ketika ada konsep yang belum dapat dikuasai dari seluruh materi yang harus dipelajarinya, atau keliru dalam menggunakan prinsip yang berlaku pada materi yang sedang dipelajarinya. Kesulitan tersebut dapat terjadi salah satunya karena proses belajar yang dialami oleh siswa tidak cukup menarik atau tidak cocok dengan karakter siswa yang bersangkutan. Kesulitan tersebut lumrah terjadi dalam pembelajaran matematika, mengingat di dalam matematika objek dasar yang dipelajari adalah abstrak menurut Hasratuddin (2014).

Kesulitan belajar menurut Subini (2011) merupakan suatu kondisi di mana kompetensi atau prestasi yang dicapai tidak sesuai dengan kriteria standar yang telah ditetapkan, baik berbentuk sikap, pengetahuan, maupun keterampilan. Proses belajar siswa yang mengalami kesulitan ditandai dengan adanya hambatan-hambatan tertentu untuk menggapai hasil belajar yang baik. Lebih rinci, Cooney (Ardiyati, 2016) menyebutkan kriteria siswa yang berkesulitan adalah: (1) siswa tidak menyelesaikan tes pada waktu yang ditentukan, dan (2) siswa menyelesaikan tes tetapi hasil penyelesaian salah. Jadi, seorang siswa dapat dikatakan sedang mengalami kesulitan dalam belajarnya apabila menunjukkan salah satu dari dua kriteria tersebut.

Pada dasarnya, dua faktor penyebab kesulitan belajar siswa, yaitu faktor internal (faktor dalam diri siswa) dan faktor eksternal (faktor yang berasal dari luar). Menurut Kustiyani (2015), faktor penyebab kesulitan belajar matematika siswa yaitu: (1) Faktor biologis, meliputi kesehatan dan cacat tubuh; (2) Faktor psikologis, meliputi intelegensi, minat, motivasi, konsentrasi, dan kebiasaan belajar; (3) Faktor lingkungan sekolah, meliputi metode mengajar, sarana dan prasarana pembelajaran, disiplin sekolah, dan waktu sekolah; (4) Faktor lingkungan keluarga, meliputi cara orang tua mendidik, pengertian orang tua terhadap anak, relasi antar anggota keluarga, keadaan ekonomi keluarga, dan suasana rumah; serta faktor yang ke (5) Faktor lingkungan masyarakat, meliputi media massa, bentuk kehidupan masyarakat, teman 
bergaul, dan kegiatan siswa dalam masyarakat. Sejalan dengan pendapat tersebut, Caryono dan Suhartono (2012) juga menyatakan bahwa terdapat lima faktor penyebab kesulitan belajar matematika, namun Caryono dan Suhartono menyebut faktor biologis sebagai faktor fisiologis.

Pendapat lainnya mengenai faktor penyebab kesulitan belajar menurut Manibuy (2014) dapat dilihat dari faktor kognitif dan faktor nonkognitif. Widyawati, dkk (2018) menggunakan faktor penyebab kesulitan siswa ditinjau dari aspek kognitif siswa, yaitu kemampuan siswa dalam penguasaan terhadap objek matematika. Pada penelitian ini, faktor penyebab siswa tidak menyelesaikan soal-soal materi limit fungsi aljabar, yaitu faktor fisiologis, psikologis, lingkungan sekolah, lingkungan keluarga, dan lingkungan masyarakat, serta mengembangkan aspek kognitif siswa menjadi faktor yang keenam yang akan diteliti, yaitu faktor materi.

Salah satu materi matematika yang sulit dikuasai oleh sebagian besar siswa, yaitu limit fungsi aljabar. Limit fungsi aljabar merupakan materi pelajaran matematika yang diajarkan ditingkat SMA/MA. Dalam menyelesaikan soal-soal limit fungsi, disamping harus menguasai rumus dan teorema limit, siswa juga dituntut untuk menguasai materi-materi prasyarat lainnya, seperti konsep pemfaktoran, merasionalkan bentuk akar, dan lain sebagainya. Jika konsep pemfaktoran, konsep bentuk akar, dan materi prasyarat untuk limit fungsi aljabar lainnya belum dikuasai oleh siswa, maka siswa akan sering melakukan kesalahan bahkan tidak mampu menyelesaikan soal-soal limit fungsi aljabar.

Adapun jenis kesulitan dalam mempelajari materi limit fungsi aljabar dimodifikasi dari jenis kesalahan dalam penelitian Salido, dkk (2017) dan jenis kesulitan menurut Wahyuni (2015). Jenis kesulitan dalam penelitian ini, yaitu jenis kesulitan konsep, kesulitan prinsip dan kesulitan prosedural. Berikut disajikan jenis kesulitan beserta indikator.

1. Kesulitan konsep. Kesulitan konsep adalah kesulitan yang dialami siswa karena tidak memahami definisi limit atau syarat-syarat sebuah fungsi memiliki limit dan kekeliruan dalam menentukan akar sekawan dari fungsi dalam bentuk akar.

2. Kesulitan prinsip. Kesulitan prinsip adalah kesulitan dalam mengaitkan beberapa fakta atau beberapa konsep. Indikator kesalahan prinsip meliputi: 1) siswa tidak memahami konsep pemfaktoran, 2) siswa tidak memahami sifat-sifat dalam operasi, dan 3) siswa tidak menguasai materi prasyarat lainnya yang digunakan dalam menentukan nilai limit sebuah fungsi.

3. Kesulitan prosedural. Kesulitan prosedural adalah kesulitan dalam pengerjaan hitung, pengerjaan aljabar, dan pengerjaan matematika yang lain. Indikator kesalahan prosedural dalam penelitian ini sebagai berikut: 1) siswa keliru dalam melakukan operasi, 2) siswa keliru dalam penulisan, 3) siswa keliru dalam subtitusi, dan 4) ketidakhirarkisan langkah-langkah dalam menentukan nilai limit fungsi.

Mengingat pentingnya mengetahui kesulitan belajar matematika yang dialami siswa, peneliti melakukan tes pada materi limit fungsi aljabar dengan memberikan soal UN Matematika SMA/MA tahun 2018/2019 materi limit fungsi aljabar yaitu sebanyak dua buah soal. Soal pertama mengenai limit di suatu titik, dan soal kedua mengenai limit di tak hingga.

Kesulitan siswa terlihat dari hasil tes yang menunjukkan masih banyak siswa yang tidak dapat menyelesaikan soal-soal tersebut. Berdasarkan hasil dari pengerjaan tes yang peneliti berikan kepada 22 orang siswa kelas XI IIS 4 MAN 1 Pekanbaru, 
diperoleh informasi bahwa lebih banyak siswa yang tidak dapat menyelesaikan soalsoal tersebut daripada siswa yang dapat menjawab baik jawaban benar maupun masih ada kesalahan. Pada soal pertama, jumlah siswa yang tidak menjawab adalah 15 orang dengan persentase $68 \%$, dan pada soal kedua, jumlah siswa yang tidak menjawab adalah 19 siswa dengan persentase $86 \%$.

Besarnya persentase jumlah siswa kelas XI IIS 4 MAN 1 Pekanbaru yang tidak menyelesaikan soal limit fungsi aljabar yang diberikan, menunjukkan bahwa banyak siswa kelas XI IIS 4 MAN 1 Pekanbaru yang belum menguasai materi limit fungsi aljabar. Asumsi ini sejalan dengan hasil penelitian oleh Raihani (2014) yang menyatakan bahwa 59\% atau lebih dari setengah jumlah siswa yang diteliti belum menguasai materi limit fungsi aljabar, sehingga tingkat kemampuan siswa pada materi limit fungsi aljabar berada pada kategori kurang. Hasil penelitian lainnya yang mendukung asumsi tersebut yaitu oleh Yuliati (2016) dan Tamrin (2012) yang menyatakan bahwa hasil pre-test siswa dalam menyelesaikan soal materi limit fungsi aljabar secara keseluruhan siswa memperoleh nilai kurang dari KKM (0\% siswa yang tuntas).

Kurangnya penguasaan siswa dan rendahnya hasil tes siswa pada materi limit fungsi aljabar, mengindikasikan adanya permasalahan siswa dalam mempelajari materi tersebut. Apabila permasalahan tersebut tidak segera diatasi, maka akan menimbulkan kesulitan dalam mempelajari materi selanjutnya, mengingat bahwa materi limit fungsi merupakan prasyarat materi turunan. Begitu pentingnya materi limit fungsi aljabar sehingga akan mempengaruhi kemampuan siswa dalam materi turunan nantinya. Sejalan dengan hal ini, Harahap (2018) menyatakan bahwa penguasaan konsep limit fungsi aljabar memiliki hubungan yang signifikan dengan hasil belajar turunan siswa. Semakin tinggi nilai penguasaan konsep limit fungsi aljabar maka akan semakin tinggi pula nilai penguasaan siswa pada materi turunan.

Agar berhasil dalam melakukan pengajaran terkait materi limit fungsi aljabar, maka sangatlah penting bagi seorang guru untuk meneliti dan mengindentifikasi apa saja yang menjadi faktor penyebab siswa tidak dapat menyelesaikan soal dalam materi limit fungsi aljabar tersebut. Selanjutnya diupayakan penyelesaian untuk meminimalkan kesulitan yang dialami siswa, sehingga siswa dapat mencapai keberhasilan dalam belajarnya. Berdasarkan uraian tersebut, peneltiian ini bertujuan untuk menganalisis faktor penyebab siswa tidak menyelesaikan soal limit fungsi aljabar, khususnya siswa di kelas XI SMA/MA.

\section{METODE}

Metode penelitian yang digunakan adalah penelitian deskriptif kualitatif. Deskriptif kualitatif di dalam penelitian ini yaitu menggambarkan faktor-faktor penyebab siswa tidak dapat menyelesaikan soal limit fungsi aljabar dengan menggunakan kata-kata. Bentuk penelitian ini adalah studi kasus. Subjek pada penelitian ini adalah siswa kelas XI IIS 4 MAN 1 Pekanbaru tahun pelajaran 2019/2020 sebanyak 22 orang siswa dengan kemampuan akademis yang heterogen.

Instrumen yang digunakan dalam penelitian ini berupa angket. Angket disebarkan untuk mengetahui faktor penyebab siswa tidak menyelesaikan soal limit fungsi aljabar berupa faktor fisiologis, psikologis, lingkungan sekolah, materi, lingkungan keluarga, dan lingkungan masyarakat. Untuk faktor materi, peneliti mengembangkan tujuh pernyataan berdasarkan kategori kesulitan menurut Salido, dkk (2017) dan divalidasi oleh salah satu dosen Program Studi Magister Pendidikan Matematika FKIP Universitas Riau. Untuk faktor lainnya, peneliti memodifikasi 
angket dari Caryono dan Suhartono (2012), dimana masing-masing faktor dikembangkan menjadi lima pernyataan.

Pada penelitian ini, data dari angket lebih lanjut dianalisis dan disajikan kedalam tabel kualifikasi faktor penyebab siswa tidak menyelesaikan soal materi limit fungsi aljabar untuk masing-masing item pernyataan, lalu dibuat pembahasan dari masing-masing faktor penyebab tersebut. Kemudian disimpulkan faktor manakah yang merupakan faktor yang termasuk dalam kualifikasi tinggi dan sangat tinggi menyebabkan siswa tidak dapat menyelesaikan soal materi limit fungsi aljabar.

Untuk mengetahui persentase faktor penyebab siswa tidak menyelesaikan soal materi limit fungsi aljabar yang dialami siswa, digunakan rumus:

Keterangan:

$$
P=\frac{F}{N} \times 100 \%
$$

$P \quad=$ Persentase Jawaban

$F \quad=$ Frekuensi Jawaban

$N \quad=$ Banyak Siswa

Persentase yang diperoleh pada masing-masing item pernyataan, kemudian ditafsirkan berdasarkan kualifikasi menurut Widyasari, dkk (2015) berikut:

Tabel 1. Kualifikasi Persentase Jawaban Angket

\begin{tabular}{cc}
\hline Persentase $(\%)$ & Kualifikasi \\
\hline $62-100$ & Sangat tinggi \\
$46-61$ & Tinggi \\
$36-45$ & Sedang \\
$22-35$ & Rendah \\
$0-21$ & Sangat rendah \\
\hline
\end{tabular}

\section{HASIL DAN PEMBAHASAN}

\section{Faktor Fisiologis}

Hasil jawaban siswa pada angket dari faktor fisiologis beserta kualifikasinya dapat dilihat pada Tabel 2 berikut.

Tabel 2. Kualifikasi Faktor Fisiologis Sebagai Penyebab Kesulitan Belajar Matematika Siswa

\begin{tabular}{clccc}
\hline No & \multicolumn{1}{c}{ Pernyataan } & $\begin{array}{c}\text { Jumlah } \\
\text { Siswa }\end{array}$ & $\begin{array}{c}\text { Persentase } \\
(\%)\end{array}$ & Kualifikasi \\
\hline 1 & $\begin{array}{l}\text { Saya sedang tidak sehat sehingga sulit } \\
\text { berkonsentrasi dalam belajar } \\
\text { Saya memiliki riwayat kesehatan yang buruk } \\
\text { sehingga mengganggu kegiatan belajar } \\
\text { Saya mempunyai kelainan fisik dan/atau } \\
\text { mental sehingga menghambat kegiatan } \\
\text { belajar }\end{array}$ & 2 & 14 & $\begin{array}{l}\text { Sangat } \\
\text { rendah } \\
\text { Kegiatan belajar saya terganggu karena } \\
\text { mengalami gangguan penglihatan (mata } \\
\text { minus, plus, dan/atau silinder) }\end{array}$ \\
$\begin{array}{l}\text { Saya mengalami gangguan pendengaran } \\
\text { sehingga menghambat kegiatan belajar }\end{array}$ & 9 & 4 & 41 & $\begin{array}{l}\text { Sangat } \\
\text { rendah }\end{array}$ \\
\hline Rata-rata & 4 & 18 & $\begin{array}{l}\text { Sangat } \\
\text { rendah }\end{array}$ \\
\hline & & 4 & $\begin{array}{l}\text { Sangat } \\
\text { rendah }\end{array}$ \\
\hline
\end{tabular}


Faktor fisiologis yang dimiliki siswa merupakan salah satu faktor yang menyebabkan kesulitan belajar matematika. Hal ini dikarenakan tidak selamanya seorang siswa memiliki fisik yang sehat dan prima ketika belajar. Akan ada kalanya kesehatan seorang siswa akan menurun. Seperti data yang peneliti peroleh, $41 \%$ siswa mengalami gangguan dalam belajar karena mengalami gangguan penglihatan (mata minus, plus, dan/atau silinder), sehingga termasuk penyebab dengan kualifikasi sedang. Seperti pada temuan penelitian oleh Mirati (2015), yang menyatakan bahwa secara fisik, siswa mengalami gangguan pada mata, dimana siswa kesulitan dalam melihat sesuatu secara fokus. Pandangannya kelihatan lebih jauh dari objek yang seharusnya.

Rata-rata, $18 \%$ siswa merasa terganggu akibat berbagai kendala fisik. Namun, rata-rata tersebut menunjukkan bahwa faktor fisiologis merupakan faktor terkecil yang menyebabkan siswa mengalami kesulitan belajar, dan merupakan satu-satunya faktor yang berada pada kualifikasi sangat rendah. Hal tersebut sejalan dengan hasil penelitian oleh Caryono dan Suhartono (2012), yang menyatakan bahwa faktor fisiologis merupakan faktor terkecil penyebab kesulitan belajar siswa, yaitu rata-rata hanya 10 dari 126 atau 8\% siswa yang merasa terganggu dengan kendala fisiknya.

Kendala fisiologis ini tetap perlu diperhatikan dengan menyarankan siswa untuk berkonsultasi kepada dokter mata jika merasa mengalami gangguan penglihatan dan guru dapat mengkondisikan tempat duduk siswa dengan menempatkan siswa-siswa yang memiliki gangguan penglihatan untuk duduk di barisan depan agar lebih nyaman dalam belajar. Selain itu berdasarkan hasil penelitiannya, Prabandari (2019) menyatakan bahwa faktor kesehatan tubuh siswa perlu diperhatikan, guru dapat mengarahkan siswa untuk menjaga kesehatannya masing-masing. Apabila siswa berada di rumah, orang tua juga sebaiknya dapat memberikan perhatian pada kesehatan siswa dengan memperhatikan waktu istirahat dan pola makan siswa.

\section{Faktor Psikologis}

Hasil jawaban siswa pada angket dari faktor psikologis beserta kualifikasinya dapat dilihat pada Tabel 3 berikut.

Tabel 3. Kualifikasi Faktor Psikologis Sebagai Penyebab Kesulitan Belajar Matematika Siswa

\begin{tabular}{|c|c|c|c|c|}
\hline No & Pernyataan & $\begin{array}{l}\text { Jumlah } \\
\text { Siswa }\end{array}$ & $\begin{array}{l}\text { Persentase } \\
\quad(\%)\end{array}$ & Kualifikasi \\
\hline 1 & $\begin{array}{l}\text { Saya merasa kesulitan belajar matematika } \\
\text { karena kurang pandai (intelegensi rendah) }\end{array}$ & 10 & 45 & Sedang \\
\hline 2 & Belajar matematika sulit dan membosankan & 13 & 59 & Tinggi \\
\hline 3 & $\begin{array}{l}\text { Minat untuk belajar matematika saya rendah } \\
\text { Saya mudah berputus asa, acuh, dan sering }\end{array}$ & 5 & 23 & Rendah \\
\hline 4 & $\begin{array}{l}\text { bolos ketika belajar matematika karena } \\
\text { motivasi belajar saya rendah }\end{array}$ & 6 & 27 & Rendah \\
\hline 5 & $\begin{array}{l}\text { Kebiasaan belajar matematika saya kurang } \\
\text { baik atau tidak belajar dengan teratur }\end{array}$ & 17 & 77 & $\begin{array}{c}\text { Sangat } \\
\text { tinggi }\end{array}$ \\
\hline & Rata-rata & 10 & 45 & Sedang \\
\hline
\end{tabular}

Kesulitan belajar siswa juga dapat timbul karena faktor psikologis siswa. Hal ini terlihat dari pernyataan Caryono dan Suhartono (2012) bahwa faktor psikologis merupakan faktor penyebab terbesar dari kelima faktor yang ia teliti. Berdasarkan data yang peneliti peroleh, diketahui bahwa faktor psikologis yang paling banyak 
dirasakan siswa adalah karena kebiasaan belajar matematika saya kurang baik atau tidak belajar dengan teratur yang menyebabkan kesulitan belajar. 17 dari 22 siswa setuju dengan pernyataan pada item kelima tersebut, sehingga persentasenya mencapai $77 \%$ dan termasuk ke dalam kualifikasi sangat tinggi. Hal ini sejalan dengan hasil penelitian yang dilakukan oleh Astuti (2015) yang menyatakan bahwa salah satu faktor penyebab siswa mengalami kesulitan dalam mempelajari matematika yaitu kebiasaan dan sikap-sikap belajar yang salah. Kemudian fakta lainnya yang peneliti peroleh yaitu, lebih banyak siswa yang merasa bahwa belajar matematika sulit dan membosankan dibandingkan yang tidak mengalaminya yang ditunjukkan dengan persentase item kedua yaitu 59\%, sehingga termasuk ke dalam kualifikasi tinggi. Hal ini sejalan dengan hasil penelitian oleh Nurhidayah (2015) yang menyatakan bahwa banyak materi matematika yang sulit dipahami oleh siswa, sehingga siswa cenderung bosan dan kurang bersemangat dalam belajar matematika.

Rata-rata jumlah siswa yang merasa terganggu akibat kendala psikologis adalah 10 siswa atau 45\% (kualifikasi sedang). Kendala ini perlu diperhatikan dengan kegiatan konseling dengan guru bimbingan konseling untuk memotivasi siswa agar belajar dengan teratur sehingga dapat mengurangi kesulitan belajar matematika kedepannya. Solusi lainnya yaitu guru mata pelajaran matematika dapat menerapkan model pembelajaran yang menuntut siswa berpartisipasi aktif, seperti yang dianjurkan dalam Kurikulum 2013. Dengan terlibatnya siswa secara aktif dalam pembelajaran dan guru bertindak sebagai fasilitator, maka akan menghilangkan rasa bosan siswa dalam belajar matematika, serta motivasi dan minat siswa mempelajari matematika semakin meningkat. Karena siswa menemukan sendiri konsep dari materi yang akan dipelajarinya dengan mengontruksi pengetahuannya sendiri, akan memperkuat konsep di diri siswa sehingga nantinya siswa dapat menyelesaikan soalsoal matematika dengan benar.

\section{Faktor Materi}

Item pernyataan faktor materi nomor 1, 4, dan 6 berkaitan dengan jenis kesulitan konsep, item nomor 3 dan 5 berkaitan dengan kesulitan prinsip, lalu item nomor 2 berkaitan dengan kesulitan prosedural. Hasil jawaban siswa pada angket dari faktor materi beserta kualifikasinya dapat dilihat pada Tabel 4 berikut.

Tabel 4. Kualifikasi Faktor Materi Sebagai Penyebab Kesulitan Belajar Matematika Siswa

\begin{tabular}{clccc}
\hline No & \multicolumn{1}{c}{ Pernyataan } & $\begin{array}{c}\text { Jumlah } \\
\text { Siswa }\end{array}$ & $\begin{array}{c}\text { Persentase } \\
(\%)\end{array}$ & Kualifikasi \\
\hline 1 & $\begin{array}{l}\text { Saya tidak paham tentang pengertian limit atau } \\
\text { syarat-syarat sebuah fungsi memiliki limit }\end{array}$ & 8 & 36 & Sedang \\
2 & $\begin{array}{l}\text { Saya sering keliru dalam pensubstitusian } \\
\text { Saya tidak mampu atau sering keliru dalam } \\
\text { memfaktorkan fungsi rasional }\end{array}$ & 13 & 59 & Tinggi \\
& $\begin{array}{l}\text { Saya tidak mampu atau sering keliru dalam } \\
\text { menyelesaikan soal limit fungsi jika salah satu } \\
\text { pembilang atau penyebut adalah bentuk akar }\end{array}$ & 17 & 77 & Tinggi \\
& $\begin{array}{l}\text { Saya tidak mampu atau sering keliru dalam } \\
\text { menyelesaikan limit dengan operasi aljabar } \\
\text { bentuk akar (penjumlahan, pengurangan, } \\
\text { perkalian, dan pembagian bentuk akar) } \\
\text { Saya tidak mengerti atau tidak mampu } \\
\text { menyelesaikan limit menuju tak hingga yaitu }\end{array}$ & 16 & 73 & Sangat \\
tinggi
\end{tabular}




\begin{tabular}{ccccc}
\hline No & Pernyataan & $\begin{array}{c}\text { Jumlah } \\
\text { Siswa }\end{array}$ & $\begin{array}{c}\text { Persentase } \\
(\%)\end{array}$ & Kualifikasi \\
\hline \multicolumn{2}{c}{$\begin{array}{l}\text { dengan membagi fungsi dengan variabel } \\
\text { pangkat tertingginya }\end{array}$} & & & \\
$\begin{array}{l}\text { Saya tidak memahami materi limit fungsi sama } \\
\text { sekali }\end{array}$ & 1 & 4 & $\begin{array}{l}\text { Sangat } \\
\text { rendah }\end{array}$ \\
\hline Rata-rata & 11 & 50 & Tinggi \\
\hline
\end{tabular}

Persentase sebesar 50\% pada faktor materi dalam kesulitan belajar siswa memperlihatkan bahwa faktor materi menjadi pilihan terbesar dari keenam faktor penyebab kesulitan belajar dan satu-satunya faktor yang termasuk dalam kualifikasi tinggi. Pada faktor materi, pernyataan dengan kualifikasi sangat tinggi yaitu pada item keempat dan kelima. Pada item keempat, sebanyak 17 siswa dengan persentase 77\% yang mengalami kesulitan konsep bentuk akar. Kemudian, item kelima memiliki persentase terbesar kedua yaitu 73\%, hal ini menggambarkan banyaknya siswa yang mengalami kesulitan prinsip dalam operasi bentuk akar.

Item kedua dan keenam memiliki persentase yang sama yaitu 59\% (kualfikasi tinggi) dan menempati urutan kesulitan terbesar kedua dari faktor materi. Pada item kedua, sebanyak 13 orang siswa mengaku sering keliru dalam pensubstitusian yang merupakan kesulitan prosedural, dan pada item keenam dengan jumlah siswa yang sama, siswa mengaku kesulitan dalam konsep limit tak hingga.

Berdasarkan informasi kesulitan belajar dari faktor materi, terlihat bahwa kesulitan terbesar siswa adalah kesulitan dalam menguasai konsep terkhusus pada materi limit fungsi dalam bentuk akar dan kemudian pada konsep limit tak hingga. Kesulitan konsep menjadi kesulitan yang dominan terjadi dalam mata pelajaran matematika juga diungkapkan oleh Jamal (2014). Kendala tersebut dapat diatasi dengan penekanan kembali dari guru terkait konsep dan prinsip bentuk akar, serta konsep limit tak hingga. Guru perlu mengulang kembali mengajarkan materi tersebut menggunakan model pembelajaran yang sesuai dengan kebutuhan materi dan karakteristik siswa yang diajar, agar siswa dapat lebih memahami dan diharapkan akan dapat menyelesaikan soal terkait materi limit dengan benar.

Mengingat bahwa materi bentuk akar sudah mulai diajarkan di kelas IX, maka solusi tersebut juga berlaku untuk guru matematika kelas IX. Jika konsep dasar dan prinsip dalam operasi aljabar bentuk akar siswa di kelas IX sudah kuat, maka ketika mempelajari limit fungsi bentuk akar siswa tidak akan mengalami kesulitan konsep dan prinsip lagi, sehingga nantinya siswa dapat menyelesaikan soal limit fungsi dalam bentuk akar dengan benar.

\section{Faktor Lingkungan Sekolah}

Hasil jawaban siswa pada angket dari faktor lingkungan sekolah beserta kualifikasinya dapat dilihat pada Tabel 5 berikut.

Tabel 5. Kualifikasi Faktor Lingkungan Sekolah Sebagai Penyebab Kesulitan Belajar Matematika Siswa

\begin{tabular}{clccc}
\hline No & \multicolumn{1}{c}{ Pernyataan } & $\begin{array}{c}\text { Jumlah } \\
\text { Siswa }\end{array}$ & $\begin{array}{c}\text { Persentase } \\
(\%)\end{array}$ & Kualifikasi \\
\hline $1 \quad \begin{array}{l}\text { Guru kurang inovatif dan kreatif dalam } \\
\text { penyampaian materi serta kurang peka } \\
\text { dengan keluhan siswa }\end{array}$ & 7 & 32 & Rendah \\
$2 \quad \begin{array}{l}\text { Sumber belajar yang tersedia kurang } \\
\text { memadai baik kuantitas ataupun kualitasnya }\end{array}$ & 10 & 45 & Sedang
\end{tabular}




\begin{tabular}{|c|c|c|c|c|}
\hline No & Pernyataan & $\begin{array}{c}\text { Jumlah } \\
\text { Siswa }\end{array}$ & $\begin{array}{c}\text { Persentase } \\
(\%)\end{array}$ & Kualifikasi \\
\hline 3 & $\begin{array}{l}\text { Kondisi kelas maupun fasilitas sekolah } \\
\text { kurang baik sehingga menghambat aktivitas } \\
\text { belajar }\end{array}$ & 10 & 45 & Sedang \\
\hline 4 & $\begin{array}{l}\text { Materi pelajaran matematika terlalu banyak } \\
\text { dan tingkat kesulitannya di atas kemampuan } \\
\text { saya }\end{array}$ & 14 & 64 & $\begin{array}{c}\text { Sangat } \\
\text { tinggi }\end{array}$ \\
\hline 5 & $\begin{array}{l}\text { Suasana belajar tidak kondusif karena waktu } \\
\text { belajar terlalu lama dan disiplin sekolah yang } \\
\text { diterapkan buruk }\end{array}$ & 9 & 41 & Sedang \\
\hline & Rata-rata & 10 & 45 & Sedang \\
\hline
\end{tabular}

Salah satu unsur penting dalam lingkungan sekolah adalah guru. Selain menguasai materi, guru harus menguasai strategi dan metode pengajaran yang sesuai dengan kebutuhan materi dan karakteristik siswa yang diajar, agar penyampaian materi akan berjalan maksimal dan menghindari kesulitan dalam belajar siswa. Selain guru, unsur dalam lingkungan sekolah yang mempengaruhi keberhasilan belajar siswa yaitu fasilitas sekolah, sumber belajar yang digunakan, kurikulum yang diterapkan, dan lain sebagainya.

Berdasarkan data kesulitan belajar siswa dari faktor lingkungan sekolah, terlihat bahwa lingkungan sekolah menjadi faktor tertinggi kedua setelah faktor materi yang menyebabkan siswa mengalami kesulitan belajar sehingga tidak dapat menyelesaikan soal limit fungsi aljabar, yaitu ditunjukkan dengan jumlah rata-rata siswa yang mengalami kesulitan sebanyak sepuluh siswa atau 45\% (kualifikasi sedang). Dimana, item keempat yaitu materi pelajaran matematika terlalu banyak dan tingkat kesulitannya di atas kemampuan siswa menjadi item terbanyak dirasakan oleh siswa. Sebanyak 14 siswa menyetujui pernyataan tersebut sehingga persentasenya menjadi $64 \%$ dan termasuk pada kualifikasi sangat tinggi. Hal ini sejalan dengan hasil penelitian Waskitoningtyas (2016) yang menyatakan bahwa salah satu faktor kesulitan belajar matematika siswa yaitu materi pelajaran matematika yang terlalu banyak, sehingga rumus yang harus dipelajari juga banyak. Untuk mengatasi kesulitan tersebut, diharapkan pihak yang berwenang mengevaluasi kurikulum yang berlaku saat ini apakah dengan komposisi materi yang dirumuskan sudah dapat mencapai tujuan pendidikan nasional, atau mengevaluasi kinerja guru apakah telah melaksanakan pembelajaran yang sesuai dengan anjuran dari kurikulum yang berlaku saat ini.

Item pernyataan kedua dan ketiga menjadi item kedua terbanyak yang disetujui siswa. Dimana siswa merasa kurangnya kualitas dan kuantitas sumber belajar, dan kondisi sekolah maupun fasilitasnya mengakibatkan situasi belajar yang kurang baik. Hal ini sejalan dengan hasil penelitian oleh Rahman (2018) dan Jamal (2014) yang menyatakan bahwa salah satu faktor yang menyebabkan kesulitan belajar matematika siswa yaitu kurangnya ketersediaan sarana dan prasarana sekolah contohnya seperti media pembelajaran dan alat peraga. Selain itu, Pradika (2014) dari hasil penelitiannya juga menyatakan bahwa siswa kesulitan dalam belajar karena siswa tidak memiliki sumber belajar lainnya selain dari guru. Sumber belajar berupa buku yang terdapat di perpustakaan sekolah jumlahnya terbatas dan akses untuk masuk perpustakaan dibatasi. Fasilitas belajar seperti meja yang disediakan sekolah untuk 
belajar jumlahnya minim, sehingga siswa harus berebut untuk dapat menggunakan meja.

Untuk mengatasi permasalahan terbatasnya sumber dan fasilitas belajar di sekolah, guru mata pelajaran sebaiknya melaporkan permasalahan ini kepada kepala sekolah atau wakil kepala sekolah bidang sarana dan prasarana. Sehingga dapat diperhatikan dan ditindaklanjuti dengan meningkatkan sarana dan prasarana yang ada agar tercipta proses pembelajaran yang lebih baik.

\section{Faktor Lingkungan Keluarga}

Hasil jawaban siswa pada angket dari faktor lingkungan keluarga beserta kualifikasinya dapat dilihat pada Tabel 6 berikut:

Tabel 6. Kualifikasi Faktor Lingkungan Keluarga Sebagai Kesulitan Belajar Matematika Siswa

\begin{tabular}{clccc}
\hline No & \multicolumn{1}{c}{ Pernyataan } & $\begin{array}{c}\text { Jumlah } \\
\text { Siswa }\end{array}$ & $\begin{array}{c}\text { Persentase } \\
(\%)\end{array}$ & Kualifikasi \\
\hline 1 & $\begin{array}{l}\text { Saya merasa tidak semangat ketika belajar } \\
\text { karena kurangnya perhatian dan dukungan } \\
\text { orang tua }\end{array}$ & 7 & 32 & Rendah \\
$\begin{array}{l}\text { Komunikasi dengan orang tua tidak baik } \\
\text { sehingga mengurangi keinginan belajar di } \\
\text { rumah }\end{array}$ & 10 & 45 & Sedang \\
$\quad \begin{array}{l}\text { Sarana untuk belajar dirumah seperti meja } \\
\text { alat tulis, buku tulis dan buku cetak yang } \\
\text { kurang memadai }\end{array}$ & 3 & 14 & $\begin{array}{l}\text { Sangat } \\
\text { rendah }\end{array}$ \\
$4 \begin{array}{l}\text { Suasana di rumah tidak nyaman untuk } \\
\text { belajar karena banyak gangguan } \\
\text { Kondisi ekonomi orang tua yang sulit } \\
\text { sehingga kebutuhan untuk belajar tidak dapat } \\
\text { dipenuhi dan menyebabkan siswa tidak } \\
\text { percaya diri dalam belajar. }\end{array}$ & 2 & 45 & Sedang \\
\hline$\quad$ Rata-rata & 5 & 23 & Rendah \\
\hline
\end{tabular}

Faktor lingkungan keluarga merupakan faktor dengan persentase terkecil kedua yang peneliti temukan setelah faktor fisiologis, artinya hanya sedikit siswa yang merasa mengalami kesulitan belajar dikarenakan lingkungan dikeluarga. Hal tersebut terlihat dari rata-rata lima orang siswa (23\%) yang mengalaminya, sehingga termasuk dalam kualifikasi rendah. Item kedua dan keempat merupakan item terbanyak dalam faktor lingkungan keluarga yang disetujui siswa, namun masih dalam kualifikasi sedang. Artinya, sepuluh dari 22 atau 45\% siswa mengaku kesulitan belajar di rumah karena komunikasi dengan orang tua tidak baik serta suasana dirumah tidak nyaman untuk belajar sehingga mengurangi keinginan belajar di rumah. Hal ini diperkuat dengan hasil penelitian oleh Luhlul (2015), Hasibuan (2018), dan Prasetyawan (2016). Hasil penelitian Luhlul (2015) dan Hasibuan (2018) menyatakan bahwa orang tua tidak menanyakan kesulitan-kesulitan belajar matematika yang dialami siswa ketika di sekolah. Prasetyawan (2016) menyatakan bahwa dengan kondisi rumah yang ramai dan gaduh, anak akan kesulitan berkonsentrasi dalam belajar.

Item pertama merupakan item terbanyak yang disetujui siswa setelah item kedua dan keempat, yaitu tujuh dari 22 orang siswa (32\%). Artinya, ketujuh orang siswa tersebut merasa kurang mendapatkan perhatian dan dukungan orang tua sehingga tidak semangat ketika belajar yang bermuara pada tidak mampunya siswa 
menyelesaikan soal, salah satunya pada materi limit fungsi aljabar yang peneliti berikan sebelumnya. Hal tersebut sejalan dengan hasil penelitian oleh Putridayani (2020) yang menyatakan bahwa salah satu faktor eksternal yang menyebabkan siswa kesulitan dalam mengerjakan soal matematika yang diberikan peneliti adalah kurangnya dukungan keluarga, sehingga tidak tercipta komunikasi yang baik antara orang tua dan anak.

Untuk mengatasi kendala dalam faktor lingkungan keluarga ini, perlu adanya koordinasi dengan dengan orang tua siswa agar dapat menciptakan suasana belajar yang tenang dan nyaman, menghindari gangguan-gangguan lainnya ketika siswa sedang belajar dirumahnya, serta menjalin komunikasi yang baik dengan anak sehingga anak dapat lebih bersemangat dalam belajar. Orang tua juga dapat membiasakan diri untuk menemani siswa ketika sedang belajar di rumah sebagai bentuk perhatian kepada anak, sehingga akan membangun kedekatan siswa dengan orang tua. Dengan mendapatkan perhatian yang cukup dari orang tua dalam belajar, maka siswa akan merasa nyaman untuk belajar di rumah. Kedekatan orang tua kepada anak akan membuat anak berani mengungkapkan permasalahan atau kesulitan yang terjadi dalam belajar nantinya (Prasetyawan, 2016).

\section{Faktor Lingkungan Masyarakat}

Hasil jawaban siswa pada angket dari faktor lingkungan masyarakat beserta kualifikasinya dapat dilihat pada Tabel 7 berikut:

Tabel 7. Kualifikasi Faktor Lingkungan Masyarakat Sebagai Penyebab Kesulitan Belajar Matematika Siswa

\begin{tabular}{clccc}
\hline No & \multicolumn{1}{c}{ Pernyataan } & $\begin{array}{c}\text { Jumlah } \\
\text { Siswa }\end{array}$ & $\begin{array}{c}\text { Persentase } \\
(\%)\end{array}$ & Kualifikasi \\
\hline 1 & $\begin{array}{l}\text { Lebih banyak menonton televisi dan bermain } \\
\text { gadget dirumah dibandingkan belajar } \\
\text { Rumah berada didekat keramaian sehingga } \\
\text { suasana menjadi ribut dan tidak } \\
\text { berkonsentrasi dalam belajar }\end{array}$ & 12 & 54 & Tinggi \\
& $\begin{array}{l}\text { Ketika pulang dari sekolah, saya sering } \\
\text { bermain dengan teman hingga merasa capek } \\
\text { dan malas untuk belajar }\end{array}$ & 12 & 54 & $\begin{array}{l}\text { Sangat } \\
\text { rendah }\end{array}$ \\
$\begin{array}{l}\text { Pentingnya pendidikan kurang disadari oleh } \\
\text { masyarakat di lingkungan sekitar saya } \\
\text { sehingga dukungan untuk belajar yang saya } \\
\text { peroleh kurang }\end{array}$ & 3 & 14 & $\begin{array}{l}\text { Sangat } \\
\text { rendah }\end{array}$ \\
$\begin{array}{l}\text { Ikut dalam berorganisasi menyebabkan saya } \\
\text { tidak dapat membagi waktu untuk belajar }\end{array}$ & 4 & 18 & $\begin{array}{l}\text { Sangat } \\
\text { rendah }\end{array}$ \\
\hline & Rata-rata & 7 & 32 & Rendah \\
\hline
\end{tabular}

Dari hasil penyebaran angket, diperoleh informasi bahwa rata-rata jumlah siswa yang mengalami kesulitan belajar karena faktor lingkungan masyarakat adalah tujuh siswa atau 32\% (kualifikasi rendah). Namun, didalam faktor lingkungan masyarakat ini, terdapat dua buah item pernyataan yang termasuk dalam kualifikasi tinggi, yaitu pada item pertama dan ketiga. Dimana, sebanyak 12 siswa (54\%) mengaku lebih banyak menonton televisi dan bermain gadget dirumah dibandingkan belajar dan ketika pulang dari sekolah, saya sering bermain dengan teman hingga merasa capek dan malas untuk belajar. Persentase sebesar 54\% pada item pertama dan ketiga tersebut menunjukkan bahwa lebih banyak siswa yang setuju bahwa kegiatan 
belajarnya terganggu karena aktivitas bermainnya, baik dengan menonton televisi, bermain game, maupun bermain dengan temannya.

Fakta bahwa besarnya pengaruh aktivitas bermain siswa di luar sekolah, baik dengan menonton televisi, bermain game, maupun bermain dengan temannya terhadap aktivitas belajar siswa juga ditemukan oleh Putridayani (2020) dan Pradika (2014) pada penelitiannya. Putridayani (2020) menyatakan bahwa faktor yang mempengaruhi kesulitan belajar siswa selain kurangnya dukungan atau motivasi dari keluarga, siswa juga kurang mendapatkan dukungan atau motivasi belajar dari teman-teman yang ada disekitar dirinya. Kemudian dilengkapi oleh hasil penelitian Pradika (2014) yang menyatakan bahwa pengaruh media massa seperti televisi, gadget, dan playstation juga membuat siswa merasa malas dan terkadang lupa untuk belajar dan mengerjakan tugasnya. Untuk mengatasi kendala tersebut, perlu bimbingan dari guru kepada siswa untuk menjelaskan pentingnya kegiatan belajar dan mengurangi frekuensi bermain agar tubuh tetap fit ketika melakukan pembelajaran. Sehingga, diharapkan ketika pembelajaran berlangsung, siswa dapat mudah mengerti dan menguasai materi yang guru ajarkan serta dapat menyelesaikan soal-soal yang guru berikan dengan benar.

\section{Rekapitulasi Seluruh Faktor Penyebab Kesulitan}

Berdasarkan rincian faktor penyebab siswa tidak menyelesaikan soal materi limit fungsi aljabar ditinjau dari kesulitan belajar dan faktor materi yang telah peneliti jabarkan, dapat diketahui proporsi dari masing-masing faktor yang telah ditetapkan, yaitu faktor fisiologis, psikologis, materi, lingkungan sekolah, lingkungan keluarga, dan lingkungan masyarakat. Adapun rekapitulasi jumlah siswa pada setiap kategori faktor penyebab kesulitan dapat dilihat pada Tabel 8 berikut.

Tabel 8. Rekapitulasi Rata-rata Jumlah Siswa pada Tiap Faktor Penyebab Kesulitan

\begin{tabular}{cccc}
\hline $\begin{array}{c}\text { Kategori Faktor Penyebab } \\
\text { Kesulitan }\end{array}$ & $\begin{array}{c}\text { Rata-rata } \\
\text { Jumlah Siswa }\end{array}$ & $\begin{array}{c}\text { Persentase } \\
(\%)\end{array}$ & Kualifikasi \\
\hline Faktor Fisiologis & 4 & 18 & Sangat rendah \\
Faktor Psikologis & 10 & 45 & Sedang \\
Faktor Materi & 11 & 50 & Tinggi \\
Faktor Lingkungan Sekolah & 10 & 45 & Sedang \\
Faktor Lingkungan Keluarga & 5 & 23 & Rendah \\
$\begin{array}{c}\text { Faktor Lingkungan } \\
\text { Masyarakat }\end{array}$ & 7 & 32 & Rendah \\
\hline
\end{tabular}

Berdasarkan Tabel 8 diatas, terlihat bahwa secara keseluruhan, faktor terbesar yang menyebabkan siswa tidak dapat menyelesaikan soal limit fungsi aljabar adalah faktor materi, dan faktor terkecil yang menyebabkan siswa tidak dapat menyelesaikan soal limit fungsi aljabar adalah faktor fisiologis. Jika pengaruh keenam faktor tersebut terhadap kemampuan siswa dalam menyelesaikan soal limit fungsi aljabar diurutkan dari yang terbesar hingga yang terkecil berdasarkan rata-rata jumlah siswa yang mengalami, maka urutannya sebagai berikut: 1) Faktor materi, yaitu dengan rata-rata jumlah siswa yang mengalami adalah 11 siswa (50\%) dengan kualifikasi tinggi; 2) Faktor psikologis dan lingkungan sekolah, yang memiliki rata-rata jumlah siswa yang mengalami dan persentase yang sama, yaitu 10 siswa (45\%) dengan kualifikasi 
sedang; 3) Faktor lingkungan masyarakat, yaitu dengan rata-rata jumlah siswa yang mengalami adalah 7 siswa (32\%) dengan kualifikasi rendah; 4) Faktor lingkungan keluarga, yaitu dengan rata-rata jumlah siswa yang mengalami adalah 5 siswa $(23 \%)$ dengan kualifikasi rendah; dan 5) Faktor fisiologis, yaitu dengan rata-rata jumlah siswa yang mengalami adalah 4 siswa $(18 \%)$ dengan kualifikasi sangat rendah.

\section{Model Pembelajaran yang dapat Mengatasi Kesulitan Belajar Matematika Siswa pada Materi Limit Fungsi Aljabar}

Mengingat bahwa beberapa penyebab kesulitan belajar matematika siswa yaitu karena siswa menganggap materi matematika sulit dan membosankan, kebiasaan belajar matematika siswa kurang baik atau tidak teratur, serta kesulitan konsep sebagai kesulitan yang dominan yang dirasakan siswa dalam belajar matematika, maka perlu dilakukan upaya oleh guru untuk dapat menghilangankan stigma-stigma negatif tersebut terhadap materi matematika. Guru dapat menerapkan model-model pembelajaran yang melibatkan siswa secara aktif dalam pembelajaran dengan menemukan konsepnya sendiri, agar pembelajaran menjadi bermakna dan tidak terasa membosankan. Jika siswa mulai menyukai belajar matematika, maka dengan sendirinya ia akan mengubah kebiasaan belajarnya menjadi lebih teratur sehingga materi matematika dapat dipahami dan kesulitan-kesulitan yang mereka rasakan akan berganti dengan hasil belajar yang lebih baik.

Salah satu model pembelajaran yang dianjurkan oleh Kurikulum 2013 yang sesuai untuk kebutuhan materi limit fungsi aljabar dan karakteristik siswa yaitu model discovery learning. Model discovery learning adalah model pembelajaran yang digunakan untuk membangun konsep dibawah pengawasan guru melalui serangkaian data atau informasi yang diperoleh dari hasil pengamatan atau percobaan yang dimulai dengan pemberian stimulus yaitu berupa permasalahan yang dapat direkayasa oleh guru, tidak harus menggunakan permasalahan autentik. Pembelajaran discovery merupakan model pembelajaran kognitif yang menuntut guru lebih kretaif menciptakan situasi yang dapat membuat siswa belajar aktif untuk menemukan pengetahuannya sendiri (Sani, 2014). Wilcox (dalam Hosnan, 2014), menyatakan bahwa dalam pembelajaran penemuan siswa didorong untuk belajar sebagian besar melalui keterlibatan aktif mereka sendiri dengan konsep-konsep dan prinsip-prinsip dan guru mendorong siswa untuk memiliki pengalaman dan melakukan percobaan yang memungkinkan mereka menemukan prinsip-prinsip untuk diri mereka sendiri.

Kelebihan model discovery learning menurut Saefudin dan Berdiati (2014) diantaranya yaitu dapat mengembangkan potensi intelektual siswa, menimbulkan rasa senang siswa karena tumbuhnya rasa menyelidiki dan berhasil, membantu siswa untuk lebih mandiri dan bertanggung jawab atas pembelajarannya sendiri, melibatkan siswa secara aktif dalam pembelajaran, memperkuat konsep dalam diri siswa, serta memperkuat memori mengenai konsep karena informasi pelajaran diperoleh sendiri oleh siswa. Hal ini sejalan dengan hasil penelitian oleh Sukma dan Supriyono (2019) yang menyatakan bahwa pembelajaran dengan model discovery learning dapat meningkatkan hasil belajar siswa pada materi limit fungsi aljabar, dimana sebelum diterapkannya model discovery learning hanya $26,47 \%$ siswa yang mencapai KKM namun setelah menerapkan model discovery learning meningkat hingga menjadi 88,24\% siswa yang telah mencapai KKM. Hasil penelitian lainnya oleh Wulandari, dkk (2017) menyatakan bahwa prestasi belajar siswa yang menggunakan modul pembelajaran limit fungsi aljabar dengan pendekatan discovery learning lebih 
baik daripada siswa yang tidak menggunakan modul pembelajaran dengan pendekatan discovery learning.

Tak hanya hasil belajar matematika siswa, namun kemampuan berpikir kritis siswa juga dapat meningkat jika diterapkan model discovery learning dalam pembelajarannya. Hal ini diperkuat dengan penelitian Purwandari (2016) yang menyatakan bahwa melalui penerapan model discovery learning yang sesuai dengan tahapan-tahapannya, maka dapat meningkatkan kemampuan berpikir kritis siswa.

\section{KESIMPULAN}

Berdasarkan hasil analisis data, dapat disimpulkan bahwa secara keseluruhan, faktor penyebab siswa tidak dapat menyelesaikan soal materi limit fungsi aljabar antara lain: 1) Faktor fisiologis sebesar 18\% (sangat rendah); 2) Faktor psikologis sebesar 45\% (sedang); 3) Faktor materi sebesar 50\% (tinggi); 4) Faktor lingkungan sekolah sebesar 45\% (sedang); 5) Faktor lingkungan keluarga sebesar 23\% (rendah); dan 6) persentase faktor lingkungan masyarakat menjadi penyebab kesulitan belajar siswa adalah 32\% (rendah). Dimana, faktor terbesar yang menyebabkan siswa tidak dapat menyelesaikan soal materi limit fungsi aljabar adalah faktor materi dengan kualifikasi tinggi. Berdasarkan informasi dari jawaban siswa yang ada pada angket, diketahui bahwa kebanyakan siswa merasa kesulitan dalam menguasai konsep serta prinsip terkhusus pada limit fungsi dalam bentuk akar dan juga pada limit tak hingga.

Adapun beberapa penyebab siswa tidak dapat menyelesaikan soal materi limit fungsi aljabar (yang termasuk dalam kualifikasi tinggi dan sangat tinggi), yaitu: 1) Kebiasaan belajar matematika siswa kurang baik atau tidak belajar dengan teratur, 2) Siswa tidak mampu atau sering keliru dalam menyelesaikan soal limit fungsi jika salah satu pembilang atau penyebut adalah bentuk akar, 3) Siswa tidak mampu atau sering keliru dalam menyelesaikan limit dengan operasi aljabar bentuk akar (penjumlahan, pengurangan, perkalian, dan pembagian bentuk akar), 4) Materi pelajaran matematika terlalu banyak dan tingkat kesulitannya di atas kemampuan siswa, 5) Siswa sering keliru dalam pensubstitusian, 6) Siswa tidak mengerti atau tidak mampu menyelesaikan limit menuju tak hingga yaitu dengan membagi fungsi dengan variabel pangkat tertingginya, 7) Siswa sering merasa belajar matematika sulit dan membosankan, 8) Siswa lebih banyak menonton televisi, bermain gadget, maupun bermain dengan temannya dirumah dibandingkan belajar, dan 9) Siswa tidak mampu atau sering keliru dalam memfaktorkan fungsi rasional.

\section{SARAN}

Untuk mengatasi kesulitan tersebut, sebaiknya guru dapat mengajarkan kembali dan menekankan konsep limit fungsi dalam bentuk akar dan limit tak hingga dengan menggunakan model pembelajaran yang sesuai dengan karakteristik siswa dan kebutuhan materi limit fungsi, yaitu model discovery learning. Serta diperlukan adanya koordinasi dengan orang tua untuk mengawasi anak agar mengurangi aktivitas bermain, meningkatkan frekuensi belajar, serta menciptakan suasana belajar yang tenang dan nyaman dirumah tanpa gangguan.

Mengingat bahwa materi bentuk akar sudah mulai diajarkan di kelas IX, maka solusi tersebut juga berlaku untuk guru matematika kelas IX. Jika konsep dasar dan prinsip dalam operasi aljabar bentuk akar siswa di kelas IX sudah kuat, maka ketika mempelajari limit fungsi bentuk akar siswa tidak akan mengalami kesulitan konsep dan prinsip lagi, sehingga nantinya siswa dapat menyelesaikan soal limit fungsi dalam bentuk akar dengan benar. 


\section{UCAPAN TERIMA KASIH}

Penelitian ini tidak menerima hibah khusus dari agensi pendanaan mana pun di sektor publik, komersial, atau nirlaba.

\section{DAFTAR PUSTAKA}

Ardiyati, R. (2016). Analisis Kesulitan Mempelajari Materi Limit Fungsi Siswa Kelas XI IPA SMAN 1 Kasihan 2013/2014. Jurnal Pendidikan Matematika-S1, 5(8), 1-11.

Astuti, F. N., Yusmin, E., \& Suratman, D. (2015). Analisis Kesulitan Pemahaman Konseptual Siswa dalam Menyelesaikan Soal pada Materi Peluang di MAN Sanggau. Jurnal Pendidikan dan Pembelajaran Khatulistiwa, 4(10), 1-10.

Azka, R. (2019). Hubungan Motivasi Belajar dan Persepsi Siswa Terhadap Gaya Mmengajar Guru dengan Prestasi Belajar Matematika. Jurnal Pengembangan Pembelajaran Matematika, 1(1), 23-31.

Caryono, S., SE, M., \& Suhartono, M. M. (2012). Analisis Deskriptif Faktor Penyebab Kesulitan Belajar Mata Pelajaran Matematika di SMA Negeri 8 Purworejo Tahun Pelajaran 2012/2013. Prosiding Seminar Nasional Matematika dan Pendidikan Matematika FMIPA UNY (pp. 819-826). Yogyakarta: Universitas Negeri Yogyakarta.

Harahap, N,. (2018). Hubungan Penguasaan Konsep Limit dengan Hasil Belajar Turunan Siswa di Kelas XI MAN Nagasaribu Kabupaten Padang Lawas Utara. Skripsi. Institut Agama Islam Negeri Padangsidimpuan.

Hasibuan, E. K. (2018). Analisis Kesulitan Belajar Matematika Siswa pada Pokok Bahasan Bangun Ruang Sisi Datar di SMP Negeri 12 Bandung. AXIOM: Jurnal Pendidikan dan Matematika, 7(1), 18-30.

Hosnan, M. (2014). Pendekatan Saintifik dan Kontekstual dalam Pembelajaran Abad 21 (p. 281). Bogor: Ghalia Indonesia.

Hasratuddin. (2014). Pembelajaran Matematika Sekarang dan yang akan Datang Berbasis Karakter. Jurnal Didaktik Matematika, 1(2), 30-42.

Jamal, F. (2019). Analisis kesulitan belajar siswa dalam mata pelajaran matematika pada materi peluang kelas XI IPA SMA Muhammadiyah Meulaboh Johan Pahlawan. MAJU: Jurnal Ilmiah Pendidikan Matematika, 1(1), 18-36.

Kustiyani, L., Susanto, \& Setiawani, S. (2015). Analisis Deskriptif Faktor Penyebab Kesulitan Belajar Matematika Siswa MA Nahdlatul Arifin Ambulu Jember. Artikel Ilmiah Mahasiswa Universitas Jember, 1(1), 1-6.

Manibuy, R. (2014). Analisis Kesalahan Siswa dalam Menyelesaikan Soal Persamaan Kuadrat Berdasarkan Taksonomi Solo Pada Kelas X SMA Negeri 1 Plus di Kabupaten Nabire-Papua. Jurnal Elektronik Pembelajaran Matematika, 2(9), 933945.

Mirati, L. (2015). Analisis Kesulitan Belajar Matematika pada Topik Logika pada Siswa SMK Muhammadiyah 3 Klaten Utara. Jurnal Pendidikan Matematika, 2(1), 25-40.

Nurhidayah, D. A. (2015). Analisis Faktor Kesulitan Belajar Matematika Siswa SMA pada Implementasi Kurikulum 2013. Prosiding Seminar Nasional Pendidikan (pp. 804-811). Ponorogo: FKIP Universitas Muhammadiyah Ponorogo.

Purwandari, T. (2016). Upaya Meningkatkan Kemampuan Berpikir Kritis dengan Model Pembelajaran Discovery Learning pada Pokok Bahasan Limit Fungsi Bagi Siswa Kelas X MIA SMA Negeri 2 Sragen. Prosiding Konferensi Nasional Penelitian Matematika dan Pembelajarannya (KNPMP I) (pp. 190-198). Surakarta: Universitas Muhammadiyah Surakarta. 
Prabandari, K. A. (2019). Analisis Faktor-faktor Penyebab Keuslitan Belajar pada Mata Pelajaran Matematika di Kelas IV SD negeri 4 Genengadal. Skripsi. Universitas Muhammadiyah Surakarta.

Pradika, K., Kriswandani, \& Yunianta, T. N. H. (2014). Analisis Faktor Eksternal Penyebab Kesulitan Belajar Mata Pelajaran Matematika Siswa Kelas VIII MTS Amal Sholeh Kecamatan Getasan. Skripsi. Universitas Kristen Satya Wacana.

Prasetyawan, D., G. (2016). Diagnosa Kesulitan Belajar Matematika Siswa Kelas IV SD Negeri Congkrang 1 Muntilan Magelang. Basic Education, 5(26), 2.481-2.488.

Putridayani, I. B., \& Chotimah, S. (2020). Analisis Kesulitan Belajar Siswa dalam Pelajaran Matematika pada Materi Peluang. Maju: Jurnal Ilmiah Pendidikan Matematika, 7(1), 57-62.

Rahman, A. A., \& Fauziana, F. (2018). Analisis Faktor Eksternal Penyebab Kesulitan Belajar Siswa SMP Melalui Pembelajaran Scientific Approach. Maju: Jurnal Ilmiah Pendidikan Matematika, 5(2), 29-40.

Raihani, D. (2014). Penguasaan Materi Prasyarat dan Kemampuan Memahami Limit Fungsi Aljabar Siswa Kelas XI SMAN 5 Banda Aceh Tahun Ajaran 2013/2014. Skripsi. Universitas Syiah Kuala.

Saefudin, A., \& Berdiati, I. (2014) . Pembelajaran Efektif (p. 56-58). Bandung: Remaja Rosdakarya.

Salido, A., Misu, L., \& Salam, M. (2017). Analisis Kesalahan Siswa dalam Menyelesaikan Soal-soal Matematika Materi Pokok Limit Fungsi pada Siswa Kelas XI IPA 2 SMA Negeri 5 Kendari. Jurnal Penelitian Pendidikan Matematika, 2(1), 1-13.

Sani, R. A. (2014). Pembelajaran Saintifik untuk Implementasi Kurikulum 2013 (p. 97). Jakarta: Bumi Aksara.

Suardi, M. (2018). Belajar dan Pembelajaran (p. 7). Yogyakarta: Deepublish.

Subini, N. (2011). Mengatasi Kesulitan Belajar Pada Anak (p. 13-14). Yogyakarta: Javalitera.

Sukma, Y., \& Supriyono, A. (2019). Peningkatan Hasil Belajar Siswa Materi Limit Fungsi Aljabar Menggunakan Discovery Learning di SMAN 10 Palembang. Lentera Sriwijaya : Jurnal Ilmiah Pendidikan Matematika, 1(2), 13-24.

Tamrin, M. (2016). Efektivitas Model Pembelajaran Creative Problem Solving (CPS) dalam Meningkatkan Hasil Belajar Siswa pada Materi Limit Fungsi Aljabar. Delta-Pi: Jurnal Matematika dan Pendidikan Matematika, 1(2), 31-42.

Wahyuni, R. S. (2015). Analisis Kesalahan dan Kesulitan dalam Menyelesaikan Soal Matematika Siswa Kelas VIII SMPN 2 Padang. Abstract of Undergraduate, Faculty of Education, Bung Hatta University, 6(1), 1-8.

Waskitoningtyas, R. S. (2016). Analisis Kesulitan Belajar Matematika Siswa Kelas V Sekolah Dasar Kota Balikpapan pada Materi Satuan Waktu Tahun Ajaran 2015/2016. Jurnal Ilmiah Pendidikan Matematika, 5(1), 24-32.

Widyasari, N. M. D., Meter, I. G., \& Negara, I. G. A. O. (2015). Analisis Kesulitankesulitan Belajar Matematika Siswa Kelas IV dalam Implementasi Kurikulum 2013 di SD Piloting Se-Kabupaten Gianyar. Mimbar PGSD Undiksha, 3(1), 1-11.

Widyawati, A., Afifah, D. S. N., \& Resbiantoro, G. (2018). Analisis Kesalahan Siswa dalam Memecahkan Masalah Lingkaran Berdasarkan Taksonomi Solo pada Kelas VIII. Jurnal Pendidikan Matematika dan Sains, 6(1), 1-9.

Wulandari, S. P., Budiyono, \& Slamet, I. (2017). Pengembangan Modul Pembelajaran dengan Pendekatan Discovery Learning pada Materi Limit Fungsi Aljabar Kelas 
X di SMA Insan Cendekia Sukoharjo Tahun Ajaran 2015/2016. Journal of Mathematics and Mathematics Education, 7(1), 1-12.

Yuliati. (2018). Pengajaran Remedial Tutor Sebaya Model Kategori Kelompok untuk Meningkatkan Hasil Belajar Matematika pada Materi Limit. Gammath: Jurnal Ilmiah Program Studi Pendidikan Matematika, 1(1), 55-61. 